\title{
Plagio, un problema emergente en la escritura académica
}

\author{
“Toda persona tiene derecho a la protección de los intereses morales y materiales que le correspondan por razón \\ de las producciones científicas, literarias o artísticas de que sea autora". \\ Declaración Universal de Derechos Humanos. Artículo 27, inciso 2.
}

La etimología nos ayuda a descubrir el origen de las palabras y la razón de su existencia. El origen latino del sustantivo plagio (plagium) se remonta al siglo III aC y su acepción era "usar al esclavo ajeno como si fuera propio". Plagium, a su vez, proviene del griego (plagios) y se utilizaba para significar un "secuestro". Pero, "las palabras tienen su evolución, el lenguaje es vivo, palpitante y posee un claro devenir histórico"(1).

Es así que este vocablo se usó por primera vez con el significado que hoy le otorgamos en el año 104 dC, siendo incorporado por la Real Academia Española recién en 1803. Se define como "copiar en lo sustancial obras ajenas, dándolas como propias”. El concepto, como veremos, está ligado al de autoría y al de derecho de autor (o copyright).

Las revistas científicas están incorporando el tema a sus procesos editoriales y, en nuestro país, la Asociación Uruguaya de Revistas Académicas (AURA) está abocada a instruir a los editores sobre las formas de prevenir y detectar este problema.

En las publicaciones pueden presentarse diferentes formas de plagio, como copiar y pegar, realizar parafraseo inadecuado, o utilizar citas falsas o perdidas (no aclaradas) ${ }^{(2)}$. La definición de autoría tiene también implicancias en el plagio, y, en este sentido, invitamos a leer el artículo especial "Autoría, desde el crédito a la responsabilidad", que tenemos el honor de publicar en forma conjunta con más de 50 revistas académicas de Europa y América, elaborado por la Red de Editores de la Sociedad Europea de Cardiología, grupo de trabajo del que forma parte nuestra revista.

Allí se expresa que "las infracciones a las reglas de autoría son una forma de engaño. Los autores invitados o ‘de regalo' y los 'fantasmas', constituyen una forma inadmisible de abuso de autoría”.

Existen indicios que pueden llevar a pensar en problemas de autoría, como nómina de autores excesivamente larga para una carta científica, o corta para un estudio aleatorizado; autores muy prolíficos que envían muchos artículos en cortos períodos, o cuando el autor no es capaz de responder a los comentarios de los revisores ${ }^{(2)}$.

El plagio académico, a nuestro juicio, agrega elementos de gravedad ya que compromete valores éticos, más allá de las eventuales connotaciones jurídicas.

En la esfera del Derecho, según la jurista Dra. Beatriz Bugallo, existe plagio toda vez que tiene lugar la usurpación de una obra ajena, o parte de ella, atribuyéndole autoría distinta de la real. Como infracción a derechos morales, el plagio en sí implica usurpación de elementos de la personalidad de un autor y "quiebra la relación entre obra y creador". El Derecho protege la obra, es decir, la concreción o formalización de una idea, pero no las ideas, porque no es posible proteger lo que aún no se materializó. La protección de la obra es lo que se llama derecho de autor. Tomar una idea ajena y darle concreción podría considerarse como "inspiración"(3).

El plagio ha tomado auge en los últimos tiempos y parece haber sido propiciado por el desarrollo de la tecnología digital que modificó sustancialmente las comunicaciones. Sin embargo, estos avances también han permitido detectarlo más fácilmente.

A instancias de SciELO y Latindex, y con la colaboración de AURA, la Revista Uruguaya de Cardiología ha incorporado el sistema antiplagio. Este sistema revisa los manuscritos a través de un programa que los contrasta con cientos de bases de datos y portales. Del resultado de este análisis se obtiene un porcentaje de similitud que informa el número total de palabras coincidentes encontradas, dividido por el total de palabras del documento. No indica en forma absoluta que el documento contiene plagio, sino que informa un porcentaje de coincidencia. En general, se establece un límite superior a $20 \%$ para sospechar plagio, pero cada resultado debe evaluarse individualmente ${ }^{(2)}$. 
El Consejo Editorial tomará decisiones luego de sopesar meticulosamente los resultados de cada caso, y cuando existan elementos confirmatorios, se comunicarán inmediatamente a los autores y el manuscrito podrá ser descartado para su publicación.

La mejor manera de prevenir el plagio académico, que en muchos casos puede ser accidental y no intencional, es jerarquizar la responsabilidad ética del autor y con honestidad intelectual, respetar a quienes han trabajado con anterioridad en el tema, referenciándolos correctamente. Asimismo, no reclamar o aceptar la autoría de un artículo sin haber participado sustancialmente en su elaboración, o dicho de otra forma, sin haber efectuado un aporte intelectual de tal magnitud que sin éste no hubiera sido posible la realización del trabajo.

El Consejo Editorial ha incorporado nuevos parámetros de transparencia a su política editorial implementando la declaración de conflictos de intereses, de contribución de cada autor, la adjudicación de DOI (digital object identifier) y actualmente el sistema antiplagio para todos los artículos, con la firme convicción de continuar mejorando la calidad de la revista en beneficio de los lectores.

Dra. María del Pilar Aguilar Passano Editora-jefe de la Revista Uruguaya de Cardiología

María del Pilar Aguilar Passano, https://orcid.org/0000-0003-4657-2808

\section{Bibliografía}

1. Aguilar B. Etimología en medicina: un viaje al origen y sentido de las palabras. Rev Urug Cardiol.2019;34(1):8-11.

2. Asociación Uruguaya de Revistas Académicas. Taller de plagio / Sistema antiplagio [diapositivas]. Asociación Uruguaya de Revistas Académicas. Montevideo: AURA; 2019.

3. Bugallo Montaño B. Sobre el plagio... esa plaga. Revista de Derecho Público. 2013; 22(44):13-42. 